\title{
Habitat utilization and conservation of the Cross River gorilla (Gorilla gorilla diehli) in Afi Mountain Wildlife Sanctuary of Cross River State, Nigeria
}

\author{
A. U. OGOGO ${ }^{1 *}$, E. A. ENIENG ${ }^{2}$ and U. S. ETTA ${ }^{1}$ \\ ${ }^{1}$ Department of Forestry and Wildlife Resources Management, University of Calabar, Calabar Nigeria. \\ ${ }^{2}$ Department of Forestry and Wildlife, University of Uyo, Uyo Nigeria. \\ "Corresponding author, E-mail: auogogo@yahoo.com
}

\begin{abstract}
The Cross River gorilla is one of Africa's most critically endangered species of primates. There is scanty information on the conservation status of this population of gorillas. This work was undertaken to ascertain the seasonal migration pattern, the feeding habits and the population status of this species of gorilla with a view to recommending the best strategies for their conservation. Two patrol teams each consisting of twelve (12) rangers were used in the study. Six sample plots $\left(240 \times 5 \mathrm{~km}\right.$ each, totaling $\left.7.2 \mathrm{~km}^{2}\right)$ were selected and used simultaneously in the northern and southern parts of the sanctuary in the rainy season and repeated in the dry season in 2006 and 2007. Data collected included the number of sites of gorilla nests, number of nests per site and plant species utilized for food by the gorillas. Student's t-test and $\mathrm{x}^{2}$ test were used to analyse data. Results indicated that the total number of nests and therefore the population of gorillas decreased significantly ( $\mathrm{p}<0.05$ ) from $616 \pm 138$ in 2006 to $405 \pm 131$ in 2007 while the mean number of gorilla nests per site also decreased significantly ( $<<0.05$ ) from $10.14 \pm 2.6$ in 2006 to $6.6 \pm 2.14$ in 2007 There was no significant reduction $(\mathrm{p}>0.05)$ in poaching activities and the number of poachers apprehended during the study period. Thirteen poachers were apprehended in 2006 as against 12 in 2007. The gorillas migrated to the northern part of the sanctuary in the dry season and moved to the south in the rainy season. A total of 32 plant species were found to have been utilized by the gorillas for food. The gorillas were found to be frugivorous but resorted to herbaceous plants when fruits were scarce. It was recommended that consultations be held with the members of the surrounding villages to dissuade them from gorilla hunting and habitat destruction.
\end{abstract}

(C) 2013 International Formulae Group. All rights reserved.

Keywords: Habitat utilization, conservation, Cross River gorilla, Afi Mountain, Nigeria.

\section{INTRODUCTION}

The Cross River gorilla (Gorilla, gorilla diehli) inhabits the forests of Nigeria Cameroon border region. This gorilla population was thought to be extinct until they were rediscovered by science in the early 1980s (Oates, 1999). This species has been identified as a distinct subspecies (Grooves, 2001; Oates, 2009). The Cross River gorilla is one of Africa's most critically endangered species of primates (Chapman et al., 2006; IUCN, 2010). According to Oates et al. (2008), the remaining population is small and fragmented, occurs outside of protected areas (especially in Cameroon) and is surrounded by some of the most densely populated human settlements in Africa. The gorilla status has become critical as human population 
continues to grow, new roads are developed, and the demand for farmlands, construction materials and forest products (including bush meat) increase. There is scanty information on the conservation status of this population of gorillas. Information on their seasonal migration pattern is also not available. Information on this species is necessary for adoption of suitable and adequate strategies for its conservation. This work was undertaken to ascertain the seasonal migration pattern, their feeding habits and the population status of this species of gorilla with a view to recommending the best strategies for their conservation.

\section{MATERIALS AND METHODS}

Afi Mountain Wildlife Sanctuary (AMWS) lies between latitude $6^{0} 25^{\prime}$ and $6^{0}$ $30^{\prime}$ north and between longitudes $8^{\circ} 45^{\prime}$ and $9^{0}$ 15 east. The mountain is a rocky massif containing several distinct rocky peaks, the highest of which is $1,300 \mathrm{~m}$ separated by deep valleys. It covers an area of about 100 square kilometres, but the study was concentrated within $40 \mathrm{~km}^{2}$ core area in which the gorillas are found (Inaoyom, pers. comm.). The sanctuary is endowed with a high primary rainforest and is the sole watershed for 16 surrounding communities. Annual rainfall is about 3,500 mm (Oates, 1999). The mountain was stratified into two sections - North and South as the two sections are separated by a mountainous ridge.

Two teams consisting of twelve (12) rangers each totalling 24 which is the total number of rangers in the sanctuary were used in the study. One team covered the northern part while the other team covered the southern part simultaneously. Each team patrolled the area for a period of two weeks at a time, 8 hours a day from 8.00 am to $4.00 \mathrm{pm}$. Radio communication was used to coordinate rangers in the field. Six plots measuring 240 $\mathrm{m}$ by $5000 \mathrm{~m}$ each (totalling $7.2 \mathrm{~km}^{2}$ ) were randomly selected from each of the sections. The plots were sampled in the dry season and the sampling was repeated in the rainy season with new plots for two years (2006 and 2007). The dry season lasted from November to March while the rainy season lasted from April to October in the area. Each ranger looked 10 metres to his right and 10 metres to his left as he walked along a transect of $5 \mathrm{~km}$ in length. On the return journey, the rangers moved freely in a random manner over the area. The gorillas were also tracked from a safe distance of about $200 \mathrm{~m}$ when encountered.

Data collected included number of sites of gorilla nests, number of nests per site, location of nests, plant species and parts utilized by the gorilla. Gorilla dung was carefully scattered with a stick and whole seeds in them were used to identify the plant species utilized for food by the gorillas. Leftover plants parts were also examined both visually and in the laboratory to identify plant species utilized. Ages of nests and dung were also noted by examining them visually and noting their stage of decomposition. Student's t-test and $\chi^{2}$ test were used to compare the number of nests found in the south with those found in the north. Estimates in the rainy season were also compared with those of the dry season using student's t-test. The number of gorilla nests per site was assumed to be the population of gorillas. These were extrapolated to obtain the figures for $40 \mathrm{~km}^{2}$ which is the area were the gorillas concentrate (Etta, 2008).

\section{RESULTS}

The number of gorilla nests found per site in the study area in 2006 and 2007 are shown in Table 1.

Results indicated that the number of nests and therefore the number of gorillas decreased significantly $(\mathrm{p}<0.05)$ from $616 \pm 138$ in 2006 to $405 \pm 131$ in 2007 . The 
mean number of gorilla nests per site also decreased significantly $(\mathrm{p}<0.05)$ from $10.14 \pm 2.6$ in 2006 to $6.6 \pm 2.14$ in $2007(95 \%$ confidence intervals). The number of nest sites which coincide with the number of social groups ranged from 8 to 11 (Table 2). There was no significant reduction $(p>0.05)$ in the number of neither poachers apprehended nor their activities between 2006 and 2007 (Table 2). A total of 580 snares were removed in the sanctuary in 2006 while 401 snares were removed from the area in 2007. Thirteen poachers were apprehended in 2006 as against 12 in 2007 and 3 hunters' sheds were destroyed in 2007.

The gorillas showed a distinct migration pattern as can be seen from the figures in Table 3 . One hundred and seventeen nests were found in the south in the wet season with no nests found in the north in the same period. On the other hand, 222 nests were found in the north in the dry season with no nest found in the south in the same period. Thus the gorillas stayed in the northern part of the sanctuary in the dry season and moved to the southern part in the rainy (wet) season.

Plant species and plant parts eaten by the gorillas are given in Table 4. Result show that the cross River gorilla is frugivorous as the fruits of all the 32 plant species listed were utilized for food by the gorillas. Over $90 \%$ of faecal samples were found to contain fruit remains.

Table 1: Number of gorilla nests found per site in northern and southern parts of Afi Mountain Wildlife Sanctuary in 2006 and 2007.

\begin{tabular}{|c|c|c|c|c|}
\hline \multirow[t]{2}{*}{ S/no. } & \multicolumn{2}{|c|}{2006} & \multicolumn{2}{|c|}{2007} \\
\hline & North & South & North & South \\
\hline 1. & 13 & 1 & 6 & 2 \\
\hline 2. & 10 & 15 & 1 & 9 \\
\hline 3. & 8 & 8 & 1 & 12 \\
\hline 4. & 11 & 8 & 11 & 4 \\
\hline 5. & 1 & 15 & 1 & 11 \\
\hline 6. & 14 & 15 & 1 & 4 \\
\hline 7. & 1 & 15 & 5 & 13 \\
\hline 8. & 8 & 3 & 4 & 6 \\
\hline 9. & 6 & 15 & - & 8 \\
\hline 10. & 15 & 16 & - & 10 \\
\hline 11. & - & 15 & - & 17 \\
\hline Total & 87 & 126 & 30 & 90 \\
\hline Mean & 8.7 & 11.45 & 3.75 & 8.72 \\
\hline Mean of means & \multicolumn{2}{|c|}{10.14} & \multicolumn{2}{|c|}{6.63} \\
\hline
\end{tabular}


Table 2: Record of poachers' apprehension and identified hunting materials in the study site between 2006 and 2007.

\begin{tabular}{llll}
\hline & \multicolumn{1}{c}{ Year } & Total \\
\cline { 2 - 3 } & $\mathbf{2 0 0 6}$ & $\mathbf{2 0 0 7}$ & \\
\hline Snare & 580 & 401 & 981 \\
Poachers & 13 & 12 & 25 \\
Hunting Sheds & 3 & 8 & 11 \\
Total & 596 & 421 & 1017 \\
\hline$\chi^{2}$ Calculated $=5.02$ & & \\
$\chi^{2}$ tabulated $=12.83$ & &
\end{tabular}

\section{DISCUSSION}

The decrease in the number of gorilla nests and therefore the number of gorillas could be attributed to the sustained poaching activities in the area. This was confirmed by the fact that poaching activities showed no significant decrease within the period of the study. In spite of enlightenment campaigns by the Cross River State Forestry Commission and the Non Governmental Organisations (NGOs), on the need to conserve the wildlife in protected areas, most hunters find it difficult to give up their old habit. Some of the hunters caught claim that they do not have an alternative profitable occupation to engage in. Other reasons for the ugly trend could be due to population increase and the introduction of sophisticated weapons in hunting in the area. Some hunters use double barrel short guns while others go as far as using AK 47 rifles especially in hunting big game like elephants and gorillas.

Wilkie et al. (1998) attributed the increase in hunting activities in Africa to population increase and the introduction of modern hunting implements such as shotguns and high powered rifles that make hunting both easier and less dangerous than the traditional hunting methods.

Nest sites varied widely in the number of nests present (1 to 17). This indicated that the Cross River gorillas are found in a range of social group sizes with 8 or fewer nests being the most common. This was also observed by Grooves and Maisels (1999), Grooves (2002) and Oates et al. (2003). Bergl et al. (2011) found nest groups ranging from 1 to 13 .

The total population of gorillas in Afi Mountain Wildlife Sanctuary could be decreasing due mainly to heavy poaching. Macfie (2007) and Oates (2009) estimated the population of gorillas in the area to range between 25 and 35 as against the 300 to 400 obtained in 2006/2007 in this study. The higher figure obtained in this study was perhaps due to the fact that the gorillas actually occupy a far smaller area than the $40 \mathrm{~km}^{2}$ range used for extrapolation in this study. The shrinkage of the gorilla range could be due to anthropogenic activities coupled with the actual reduction in the population.

The northern part of the sanctuary with a high human population is frequently burnt in the dry season which gives rise to a number of herbaceous plants like Afromonium spp and Custus afa which the gorillas utilize for food. This explains why the gorillas were found exclusively in the north during the dry season. Food and safety are the major determinants of the gorilla's movement. In the rainy season, fruits become abundant in the southern part which is more forested than the northern part, hence the movement of the gorillas to the south in the rainy season. Thus Rangers' patrols and other protection activities should be concentrated in the northern part of the sanctuary in the dry season and in the southern part in the rainy season. The high diversity of plant species eaten by the gorillas and their frugivorous habit suggests that the gorillas require a relatively undisturbed forest to thrive. Oates et al. (2004) also observed this high diversity of food species in the Western lowland gorillas. The gorilla's diet also reflected the seasonal nature of their habitat showing marked shift in composition between seasons of the year. When fruits were scarce, the gorillas appeared to rely on herbaceous vegetation. Two herb species most frequently eaten were Amorphophallus difomis and Afromonum spp. This habit was also reported by Mcfarland (2001). 
A. U. OGOGO et al. / Int. J. Biol. Chem. Sci. 7(4): 1579-1585, 2013

Table 3: Total Number of gorilla nests found in the dry and wet seasons in the study area.

\begin{tabular}{lccc}
\hline & North & South & Total \\
\hline Wet season & 0 & 117 & 117 \\
Dry season & 222 & 0 & 222 \\
Total & 222 & 117 & 339 \\
\hline$\chi^{2}$ tabulated $=$ 9.348 & & \\
$\chi^{2}$ calculated $=$ 339. Sig. $(\mathrm{p}<0.05)$ & &
\end{tabular}

Table 4: Plant species utilized by the cross River gorilla in Afi Mountain Wildlife Sanctuary in 2006 and 2007.

\begin{tabular}{|c|c|c|c|c|c|c|c|c|}
\hline \multirow[t]{2}{*}{ S/no } & \multirow[t]{2}{*}{ Species } & \multirow[t]{2}{*}{ Family } & \multirow[t]{2}{*}{ Common name } & \multicolumn{5}{|c|}{ Part eaten } \\
\hline & & & & Bark & Root & Leaves & Fruit & Pith \\
\hline 1. & Antrocanryon micraster \# & Anacardiacea & Ojif & & & & $*$ & \\
\hline 2. & Dennettia tripetala & & & & & & * & \\
\hline 3. & Landolphia oweriensisP & Annonaceae & Mmimi & & & & $*$ & $*$ \\
\hline 4. & Landolphia sp.\# & & & & & & * & \\
\hline 5. & Canarium scshweinfurthii \# & Apocynaceae & White rubber vine & & & & * & \\
\hline 6. & Dacryodes edulis & Apocynaceae & Bushu-basong & & & & * & \\
\hline 7. & Santiria trimera \# & Burseraceae & Bushu & & & & $*$ & \\
\hline 8. & Diallum guineense \# & & & & & $*$ & * & \\
\hline 9. & Guibourtia ehie & Burseraceae & & & & & $*$ & \\
\hline 10. & Caloncoba giauca & Burseraceae & & & & & $*$ & \\
\hline 11. & Garcinia kola & Caesalpiniodeae & Komon & & & & $*$ & \\
\hline 12. & Irvingia gabonensis & Caesalpiniodeae & Icheku & & & & * & \\
\hline 13. & Napoleona vogeili & Flacourtiaceae? & Udala enwe & & & & $*$ & \\
\hline
\end{tabular}


A. U. OGOGO et al. / Int. J. Biol. Chem. Sci. 7(4): 1579-1585, 2013

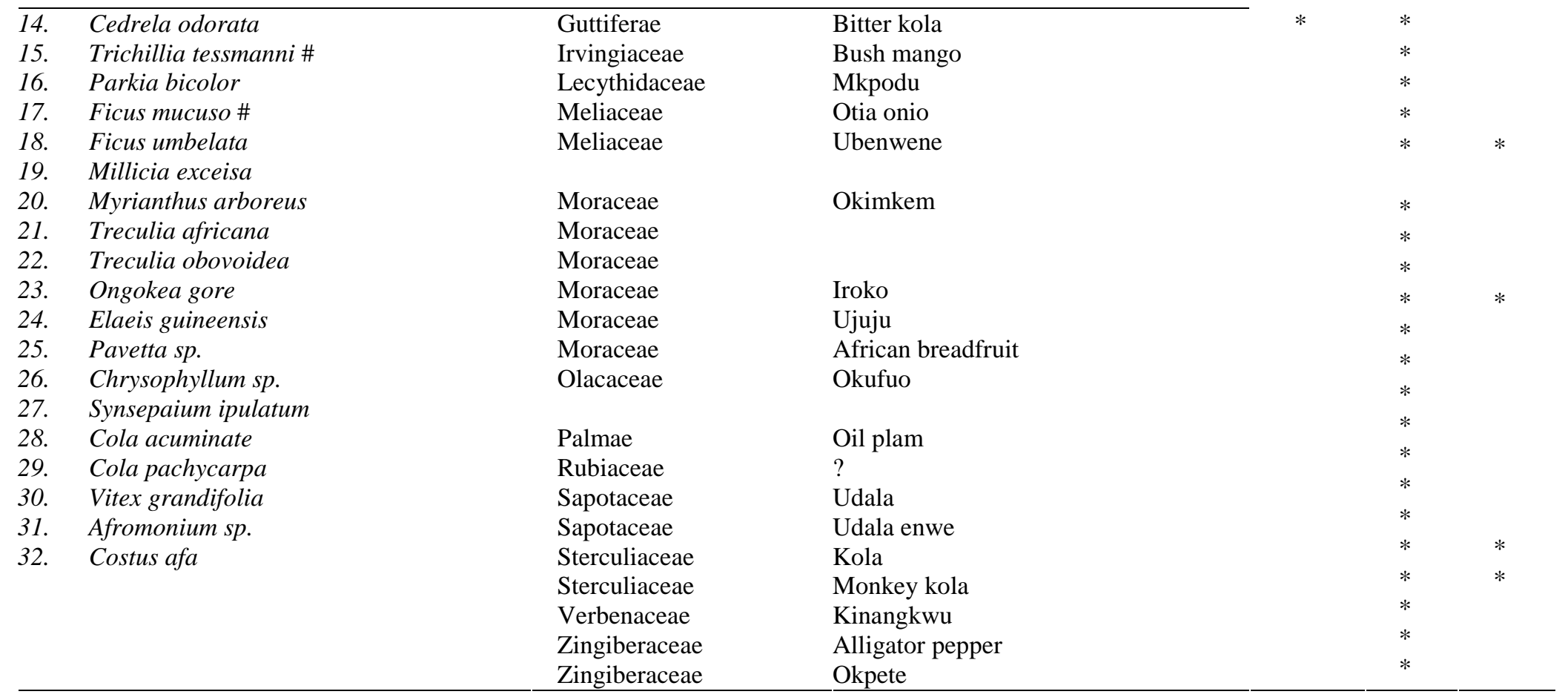




\section{Conclusion}

The gorillas in Afi Mountain Wildlife Sanctuary migrate to the northern part of the sanctuary in the dry season and move to the southern part in the rainy season. The gorillas are mainly frugivorous and utilize a high diversity of plant species for food. They resort to herbaceous plant spp. especially in the dry season when fruits are scarce. The gorillas exist mostly in small social group sizes of between 2 and 17 . Poaching activities have not been reduced over the years and the population of the gorillas may be decreasing. It was recommended that more consultations be held with the members of the surrounding villages to dissuade them from hunting the gorillas, regular population census be carried out to ascertain the trend of the population of gorillas in the sanctuary.

\section{REFERENCES}

Bergl RA, Vigilant L. 2007 Genetic analysis reveals population structure and recent migration within the highly fragmented range of the Cross River gorilla. Molecular Ecology, 16: 501-516.

Chapman CA, Lawes M, Eeley HAC. 2006. What hope for African primate diversity? Afr. J. Eco., 44: 116-133.

Etta US. 2008. Conservation Strategies of Cross River Gorilla (Gorilla gorilla diehli) in the Afi mountain Wildlife Sanctuary, Cross River State, Nigeria. M.Sc thesis, University of Uyo.

Grooves CP. 2001. Primate Taxonomy. Smithsonian Institute Press: Washington, D. C.

Grooves JL, Maisels F. 1999. Report on the large mammals fauna of the Takamanda Reserves, South West Province, Cameroon with special emphasis on the gorilla population. WWF Cameroon programme.

IUCN 2010. Red List of Threatened Species v. 2010.4. Http://www.iucnredlist.org accessed $2^{\text {nd }}$ August 2013.

Macfie EJ. 2007. Studying the potential of gorilla-based tourism as a possible tool for the long-term conservation and management of the Afi Mountain Wildlife Sanctuary, Cross River State, Nigeria. Final Report.
McFarland KL. 2007. Ecology of Cross River Gorillas (Gorilla gorilla diehli) on Afi Mountain, Cross River State, Nigeria. Ph.D. Thesis, Graduate Center, City University of New York, New York.

Oates JF. 1999. Myth and Reality in the Rainforest. University of California Press: Berkley U.S.A. Pp.29-100.

Oates JF, McFarland KL, Grooves JL, Bergl RA, Linder JM, Disotell TR. 2003. The Cross River gorilla: Natural history and status of a neglected and critically endangered subspecies. In Gorilla Biology: A Multidisciplinary Perspective, Taylor A, Goldsmith ML (eds). Cambridge University Press: Cambridge.

Oates JF, Bergl RA, Linder JM. 2004. Africa's Gulf of Guinea Forests: Biodiversity Patterns and Conservation Priorities. International Center for Applied Biodiversity, Science: Washington D. C., U.S.A.

Oates JF, Bergl RA, Sunderland-Groves JA. 2008. Gorilla gorilla ssp. diehli. In IUCN Red List of Threatened Species. Version 2013.1. <www.iucnredlist.org>. Downloaded on 02 August 2013.

Oates JF. 2009. Biodiversity of the Afi forest complex, Cross River State, Nigeria: A Desk Study.

Plunptre AJ, McNeilage A, Hall JS, Williamson E. 2003. The current Status of Gorillas and threats to their existence at the beginning of a new Millenium. In Gorilla Biology: A Multidisciplinary Perspective, Taylor A, Goldsmith M (eds). Cambridge University Press: Cambridge.

Rogers ME, Abemethy K, Bermejo M, Cipolletta C, Doram D McFarland K, Nishihara T, Remis M, Turin CEG. 2004. Western gorilla diet: A synthesis from six sites. Am. J. Prim., 64: 173-192.

Samiento EE, Oates JF. 2000. The Cross River gorilla: a distinct subspecies Gorilla gorilla diehli Matsche. American Museum Novitates, 3304: 1-55.

Werikhe S, Macfie L, Rosen N, Miller P. 1998. Can the Mountain Gorilla Survive? Population and Habitat Viability Assessment for Gorilla gorilla beringei. IUCN, SSC Conservation Breeding Specialist Group, Apple Valley. MN. 